\title{
Heavy metals in the bottom sediments of the coastal zone of the eastern part of the Gulf of Finland
}

\author{
Valentina Kudryavtseva*, Tatyana Shigaeva, and Natalya Alekseeva
}

St. Petersburg Federal Research Centre of the Russian Academy of Science (SPC RAS), Scientific Research Center for Ecological Safety of the Russian Academy of Sciences, 197110 18, Korpusnaya str., St. Petersburg, Russia

\begin{abstract}
For each summer from 2014 to 2019 the total concentrations of copper, zinc, cadmium, and lead in the surface layers of bottom sediments in the coastal zone of the eastern part of the Gulf of Finland were measured. The northern coast in the area of the city of Primorsk currently sees the rate of the pollution of surface-level bottom sediments with heavy metals decrease, although the concentration levels remain high. On the southern coast in the area of the city of Lomonosov the pollution of the bottom sediments is on the rise due to the ongoing construction of the Bronka seaport. In the Koporskaya and Grafskaya Bays a massive growth of macroalgae caused a further accumulation of metals in the bottom sediments, which are greatly impacted by climatic fluctuations.
\end{abstract}

\section{Introduction}

St. Petersburg and the coastal areas of the Leningrad Oblast are located on the eastern coast of the Gulf of Finland. An extreme human-induced burden placed on the waters of the Gulf of Finland by megacities, industry, agriculture, transport, intense dredging, and port construction leads to water contamination and the accumulation of pollutants in modern sedimentation basin silts [1]. River run-off, surface flush from the water-collecting area, wastewaters, intrabasin processes, as well as exchanges in the "water - bottom sediment" system cause major harm to the eastern part of the Gulf of Finland. Heavy metals and biogens pollute the coastal waters on the south of the eastern coast of the Gulf of Finland, which has led to severe environmental problems in a number of places on the coast (the city of Lomonosov, Grafskaya Bay, Koporskaya Bay) [2].

Bottom sediments is an essential component of surface water bodies and have a significant impact on aquatic ecosystems. On the one hand, by accumulating contaminants through the process of sedimentation and adsorption, bottom sediments contribute to selfpurification of the aqueous medium. On the other hand, bottom sediments may become a major source of secondary contamination of adjacent waters due to the migration of accumulated substances under conditions that are favorable for this process [3]. Compounded by boundary effects, climate change and the increasing human-induced burden are responsible for the major, particularly negative, transformation of coastal sea bay environment [4]. Compared to open-sea waters, the chemical composition of coastal-sea waters is characterised by increased spatial-temporal variability. Although numerous scientific works have been published on the topic of the environmental state of coastal sea

* Corresponding author: valenkud@yandex.ru 
bays, bottom sediment pollution, and diagenesis, many of the issues related thereto are still subject to much discussion and remain areas of uncertainty. Taking into consideration the climate change over the recent years, a study of the migration and distribution of chemical elements between bottom sediments and a water layer becomes especially relevant.

In order to comprehensively describe the ecological state of bottom sediments in bodies of water, it is necessary to determine the spatial and temporal distribution of heavy metals in bottom sediments.

The purpose of this work is to analyse the content of a group of heavy metals $(\mathrm{Cu}, \mathrm{Zn}$, $\mathrm{Cd}, \mathrm{Pb}$ ) stored in the coastal zone bottom sediments in the eastern Gulf of Finland for each summer from 2014 to 2019.

\section{Research materials and methods}

The research was conducted at 9 observation stations in the coastal shallow of the eastern part of the Gulf of Finland during the summer periods of 2014-2019. The examined material was a bottom sediment upper layer sample $(0-5 \mathrm{~cm})$ collected by the "Robur" sampler. The samples were extracted approximately 10 meters from the shore at a depth of 0.5 meters. Each sample was gathered in quadruplicate.

Figure 1 shows the location of the stations at which the bottom sediment samples were collected.

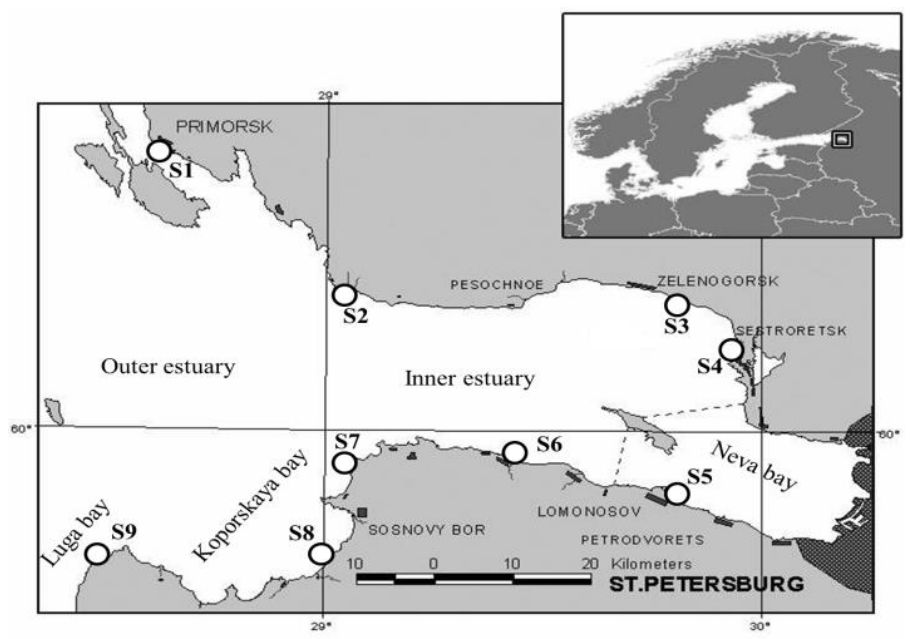

Fig. 1. Location of the sampling sites (white circles) in the eastern Gulf of Finland.

The stations were located on the northern and the southern coasts of the eastern part of the Gulf in places directly influenced by human activity. More precisely, places by seaports and marine terminals (Lomonosov, Primorsk), in proximity to a highway (Bolshaya Izhora), in the areas of the Gulf that are almost fully covered with a layer of phytobenthos and phytoplankton (Grafskaya Bay, Koporskaya Bay, Cape Flotsky), as well as those not subject to external anthropogenic influence (Repino, Dubki, Luzhskaya Bay). The coordinates of the stations were calculated and tracked by the GPS navigation system with the error is \pm 5 meters.

To conduct a chemical and physic-chemical analysis the bottom sediment samples were dried in a desiccator at a temperature of $30^{\circ} \mathrm{C}$ to a constant mass. After that they were sieved to collect fractions fewer than $1 \mathrm{~mm}$ in diameter. The total concentrations of metals $(\mathrm{Cu}, \mathrm{Zn}$, $\mathrm{Pb}, \mathrm{Cd}$ ) in the bottom sediments was determined with the Agilent 7700x inductively coupled 
plasma mass spectrometry (ICP-MS) instrument (“Agilent technologies", Japan). The Eh and $\mathrm{pH}$ levels were measured with a "pH 420" meter (“Aquilon”, Russia). The measuring electrodes set included a combined oxidative-reductive electrode InLab®Redox made up of a platinum ring indicator electrode and a silver/silver chloride reference electrode and a combined $\mathrm{pH}$ electrode composed of a glass $\mathrm{pH}$ electrode and a reference electrode.

The granulometric analysis of the bottom sediments was conducted based on the laser method, namely using the LA-950 Horiba analyzer (Japan).

\section{Results and discussion}

Table 1 shows the results of an experiment that reveal physic-chemical properties of bottom sediments at the 9 stations on the northern and the eastern coasts of the Gulf of Finland.

Table 1. Physical and chemical parameters of the sediments at the sampling sites.

\begin{tabular}{|c|c|c|c|c|c|}
\hline Site & Locat & & Year & pH & Eh, mV \\
\hline S1 & Primorsk & $\begin{array}{l}60^{\prime} 21^{\prime} 54 \mathrm{~N} \\
28^{\prime} 36^{\prime} 42 \mathrm{E}\end{array}$ & $\begin{array}{l}2017 \\
2018 \\
2019 \\
\end{array}$ & $\begin{array}{l}7.1 \pm 0.2 \\
6.6 \pm 0.2 \\
6.8 \pm 0.2\end{array}$ & $\begin{array}{c}90 \\
-43 \\
-50 \\
\end{array}$ \\
\hline S2 & Cape Flotsky & $\begin{array}{l}60^{\prime} 09^{\prime} 44 \mathrm{~N} \\
29^{\prime} 09^{\prime} 07 \mathrm{E}\end{array}$ & $\begin{array}{l}2017 \\
2018 \\
2019\end{array}$ & $\begin{array}{l}6.2 \pm 0.2 \\
6.2 \pm 0.2 \\
7.2 \pm 0.2\end{array}$ & $\begin{array}{l}290 \\
-45 \\
183 \\
\end{array}$ \\
\hline S3 & Repino & $\begin{array}{l}60^{\prime} 09^{\prime} 44 \mathrm{~N} \\
29^{\prime} 51^{\prime} 16 \mathrm{E}\end{array}$ & $\begin{array}{l}2016 \\
2018 \\
2019 \\
\end{array}$ & $\begin{array}{l}7.3 \pm 0.2 \\
6.6 \pm 0.2 \\
6.8 \pm 0.2\end{array}$ & $\begin{array}{c}56 \\
263 \\
-54 \\
\end{array}$ \\
\hline S4 & Dubki & $\begin{array}{l}60^{\prime} 05^{\prime} 24 \mathrm{~N} \\
29^{\prime} 55^{\prime} 11 \mathrm{E}\end{array}$ & $\begin{array}{l}2016 \\
2017 \\
2018 \\
2019\end{array}$ & $\begin{array}{l}6.8 \pm 0.2 \\
6.9 \pm 0.2 \\
6.9 \pm 0.2 \\
6.8 \pm 0.2\end{array}$ & $\begin{array}{c}33 \\
81 \\
160 \\
6 \\
\end{array}$ \\
\hline S5 & Lomonosov & $\begin{array}{l}59^{\prime} 89^{\prime} 29 \mathrm{~N} \\
29^{\prime} 34^{\prime} 14 \mathrm{E}\end{array}$ & $\begin{array}{l}2016 \\
2017 \\
2018 \\
2019 \\
\end{array}$ & $\begin{array}{l}7.0 \pm 0.2 \\
7.2 \pm 0.2 \\
7.3 \pm 0.2 \\
7.0 \pm 0.2 \\
\end{array}$ & $\begin{array}{c}44 \\
-40 \\
-38 \\
-24 \\
\end{array}$ \\
\hline S6 & Big Izhora & $\begin{array}{l}59^{\prime} 56^{\prime} 04 \mathrm{~N} \\
29^{\prime} 54^{\prime} 18 \mathrm{E}\end{array}$ & $\begin{array}{l}2017 \\
2018 \\
2019 \\
\end{array}$ & $\begin{array}{l}6.7 \pm 0.2 \\
6.5 \pm 0.2 \\
7.0 \pm 0.2\end{array}$ & $\begin{array}{r}30 \\
74 \\
-14 \\
\end{array}$ \\
\hline S7 & Grafskaya Bay & $\begin{array}{l}59^{\prime} 58^{\prime} 85 \mathrm{~N} \\
29^{\prime} 12^{\prime} 51 \mathrm{E}\end{array}$ & $\begin{array}{c}2016 \\
2017 \\
2018 \\
21019 \\
\end{array}$ & $\begin{array}{l}6.8 \pm 0.2 \\
6.6 \pm 0.2 \\
7.0 \pm 0.2 \\
7.3 \pm 0.2 \\
\end{array}$ & $\begin{array}{c}-103 \\
-170 \\
-102 \\
-99 \\
\end{array}$ \\
\hline S8 & Koporskaya Bay & $\begin{array}{l}59^{\prime} 48^{\prime} 25 \mathrm{~N} \\
28^{\prime} 53^{\prime} 48 \mathrm{E}\end{array}$ & $\begin{array}{l}2016 \\
2017 \\
2018 \\
2019\end{array}$ & $\begin{array}{l}7.4 \pm 0.2 \\
6.8 \pm 0.2 \\
7.1 \pm 0.2 \\
7.3 \pm 0.2\end{array}$ & $\begin{array}{l}-60 \\
-28 \\
-72 \\
-90\end{array}$ \\
\hline S9 & Luga Bay & $\begin{array}{l}59^{\prime} 46^{\prime} 54 \mathrm{~N} \\
28^{\prime} 26^{\prime} 41 \mathrm{E}\end{array}$ & $\begin{array}{l}2016 \\
2017 \\
2018 \\
2019\end{array}$ & $\begin{array}{l}6.8 \pm 0.2 \\
7.0 \pm 0.2 \\
7.0 \pm 0.2 \\
6.9 \pm 0.2\end{array}$ & $\begin{array}{c}73 \\
29 \\
186 \\
81\end{array}$ \\
\hline
\end{tabular}

The upper layer of bottom sediments showed a low concentration of organic carbon (from 
$0.1 \%$ to $0.8 \%$ ) [5]. At the majority of observation stations over the period from 2016 to 2019 the $\mathrm{pH}$ level was close to neutral values (6.6-7.4). The only exception was the S2 station, where in 2017 and 2018 a slightly acidic reaction was observed (pH 6.2). The level of reduction-oxidation potential Eh (Eh relative of the hydrogen electrode) in the surface layer of bottom sediments along the coast varied significantly (by 300-400 mV). In 2019 at the S1, S3, S4 and S6 stations there was a trend towards the acidification of the bottom sediments and a decrease in the Eh levels. During the researched period the presence of many rotting algae in the coastal zone of the S7 and S8 stations caused the reducing conditions of the bottom sediments.

The research [6] includes the study of the granulometric composition of the bottom sediments sampled from the coastal area of the eastern part of the Gulf of Finland. The granulometric analysis revealed that the surface layer of bottom sediments predominantly consisted of sandy fractions with an insignificant amount of clay particles (less than 10\%). The X-ray diffraction analysis showed that the samples also included ferriferous fractions. The study found a positive correlation between label forms of copper, zinc compounds, and iron compounds $(\mathrm{p}<0.05)$, which proves that iron compounds contribute to the accumulation of heavy metals in bottom sediments [6].

In the summers of 2016-2018 the research group conducted a granulometric analysis of the bottom sediment samples gathered at all the stations with the LA-950 analyser. The average particle size varied from 150 to $350 \mu \mathrm{m}$. The algae samples of bottom sediments from the Koporskaya station attracted the highest interest where the analysis showed a several-fold increase in particle size $(600 \mu \mathrm{m})$.

An X-ray phase analysis was conducted to determine a phase composition of the bottom sediments. The table 2 shows the results of the analysis.

Table 2. Phase composition of the samples of the bottom sediments.

\begin{tabular}{|c|c|}
\hline Location & Phase composition \\
\hline Primorsk & $\mathrm{SiO}_{2}, \mathrm{Fe}_{2} \mathrm{~S}_{2} \mathrm{O}_{9} \cdot \mathrm{xH}_{2} \mathrm{O}, \mathrm{NaHSi}_{2} \mathrm{O}_{5}, \mathrm{NaAlSi}_{3} \mathrm{O}_{8}, \mathrm{Na}_{6} \mathrm{Si}_{8} \mathrm{O}_{19}$ \\
\hline Big Izhora & $\mathrm{SiO}_{2}, \mathrm{Na}_{6} \mathrm{Si}_{8} \mathrm{O}_{19}, \mathrm{Fe}_{2} \mathrm{~S}_{2} \mathrm{O}_{9} \cdot \mathrm{xH}_{2} \mathrm{O},(\mathrm{Na}, \mathrm{K})\left(\mathrm{Si}_{3} \mathrm{Al}\right) \mathrm{O}_{8}$ \\
\hline Koporskaya Bay & $\mathrm{SiO}_{2}, \mathrm{Fe}_{2} \mathrm{~S}_{2} \mathrm{O}_{9} \cdot \mathrm{xH}_{2} \mathrm{O},(\mathrm{Na}, \mathrm{K})\left(\mathrm{Si}_{3} \mathrm{Al}\right) \mathrm{O}_{8}$ \\
\hline Luga Bay & $\begin{array}{l}\mathrm{SiO}_{2}, \mathrm{Fe}_{2} \mathrm{~S}_{2} \mathrm{O}_{9} \cdot \mathrm{xH}_{2} \mathrm{O}, \mathrm{NaHSi}_{2} \mathrm{O}_{5}, \mathrm{Na}_{6} \mathrm{Si}_{8} \mathrm{O}_{19} \\
(\mathrm{Na}, \mathrm{K})\left(\mathrm{Si}_{3} \mathrm{Al}\right) \mathrm{O}_{8}, \mathrm{Fe}_{2} \mathrm{Al}_{2}\left(\mathrm{SiO}_{4}\right)^{3}\end{array}$ \\
\hline Dubki & $\mathrm{SiO}_{2}, \mathrm{Fe}_{2} \mathrm{~S}_{2} \mathrm{O}_{9} \cdot \mathrm{xH}_{2} \mathrm{O}, \mathrm{NaHSi}_{2} \mathrm{O}_{5}, \mathrm{Na}_{6} \mathrm{Si}_{8} \mathrm{O}_{19}$ \\
\hline Grafskaya Bay & $\mathrm{SiO}_{2}, \mathrm{Fe}_{2} \mathrm{~S}_{2} \mathrm{O}_{9} \cdot \mathrm{xH}_{2} \mathrm{O}, \mathrm{Ca}_{3} \mathrm{Mn}\left(\mathrm{SO}_{4}\right)^{2}(\mathrm{OH})_{6} \cdot 3 \mathrm{H}_{2} \mathrm{O}$ \\
\hline Cape Flotsky & $\begin{array}{l}\mathrm{SiO}_{2}, \mathrm{Fe}_{2} \mathrm{~S}_{2} \mathrm{O}_{9} \cdot \mathrm{xH}_{2} \mathrm{O},(\mathrm{Na}, \mathrm{K})\left(\mathrm{Si}_{3} \mathrm{Al}\right) \mathrm{O}_{8}, \\
\mathrm{Ca}_{3} \mathrm{Mn}\left(\mathrm{SO}_{4}\right)^{2}(\mathrm{OH})_{6} \cdot 3 \mathrm{H}_{2} \mathrm{O}\end{array}$ \\
\hline Lomonosov & $\mathrm{SiO}_{2}, \mathrm{Fe}_{2} \mathrm{~S}_{2} \mathrm{O}_{9} \cdot \mathrm{xH}_{2} \mathrm{O}, \mathrm{Ca} 3 \mathrm{Mn}\left(\mathrm{SO}_{4}\right)^{2}(\mathrm{OH})_{6} \cdot 3 \mathrm{H}_{2} \mathrm{O}$ \\
\hline
\end{tabular}

According to the diffractorgams, $\mathrm{SiO} 2$ was a basified phase in all samples that contained sand. Additionally, the samples contained small amounts of impurity phases such as $\mathrm{NaHSi}_{2} \mathrm{O}_{5}, \mathrm{Fe}_{2} \mathrm{~S}_{2} \mathrm{O}_{9} * \mathrm{xH} 2 \mathrm{O}, \quad(\mathrm{Na}, \mathrm{K})\left(\mathrm{S}_{\mathrm{i} 3} \mathrm{Al}\right) \mathrm{O}_{8}, \mathrm{Na}_{6} \mathrm{Si}_{8} \mathrm{O}_{19}, \mathrm{NaAlSi}_{3} \mathrm{O}_{8}, \mathrm{Fe}_{2} \mathrm{Al}_{2}\left(\mathrm{SiO}_{4}\right)^{3}$ и $\mathrm{Ca}_{3} \mathrm{Mn}\left(\mathrm{SO}_{4}\right)^{2}(\mathrm{OH})_{6} \cdot 3 \mathrm{H}_{2} \mathrm{O}$. $(\mathrm{Na}, \mathrm{K})\left(\mathrm{Si}_{3} \mathrm{Al}\right) \mathrm{O}_{8}$.

The results of scanning electron microscopy of the bottom sediments sampled at the Dubki station revealed a layered structure of the particles. Some of them were surrounded by a layer of fine particles of various origin. 


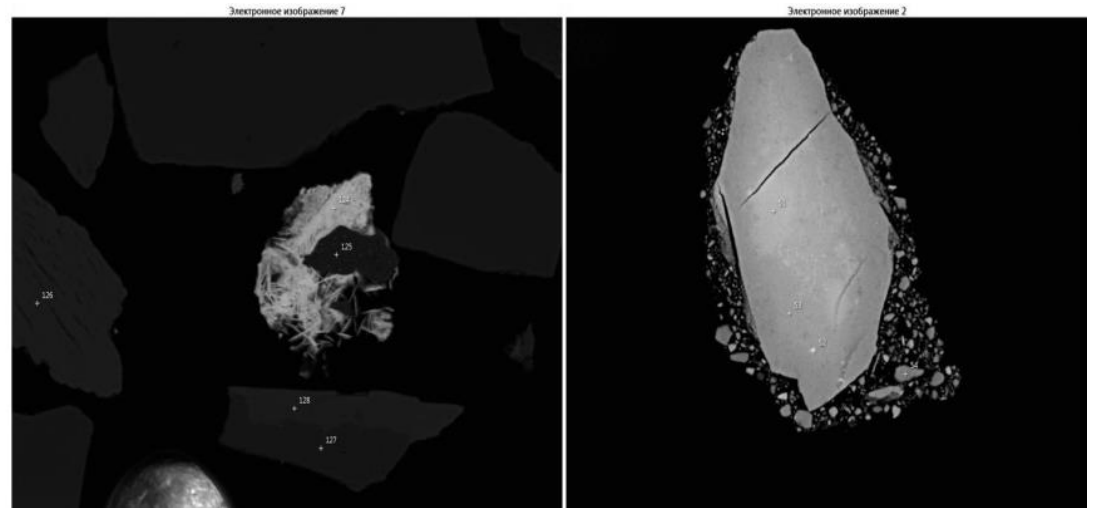

Fig. 2. Micrograph of the bottom sediments of Dubki station.

The differences in dispersion, samples' phase compositions, and in the number of layers on the surface of particles suggest a varying sorption capacity of heavy metals.

Table 3 shows the total concentrations of heavy metals $(\mathrm{Cu}, \mathrm{Zn}, \mathrm{Cd}, \mathrm{Pb})$ in the bottom sediments of the Gulf of Finland coastal zone for each summer from 2014 to 2019.

Table 3. Total metal content in the bottom sediments of the coastal zone of the eastern Gulf of Finland (ppm).

\begin{tabular}{|c|c|c|c|c|c|c|}
\hline № & Location & Year & $\mathrm{Cu}$ & Zn & Cd & $\mathbf{P b}$ \\
\hline \multirow{4}{*}{$\mathrm{S} 1$} & \multirow{4}{*}{ Primorsk } & 2014 & $55.70 \pm 7.12$ & $66.12 \pm 7.20$ & $0.16 \pm 0.04$ & $32.67 \pm 6.59$ \\
\hline & & 2017 & $22.91 \pm 3.43$ & $45.41 \pm 3.62$ & $0.09 \pm 0.03$ & $25.21 \pm 5.04$ \\
\hline & & 2018 & $13.44 \pm 1.21$ & $27.81 \pm 2.51$ & $0.18 \pm 0.04$ & $25.72 \pm 4.97$ \\
\hline & & 2019 & $11.21 \pm 1.34$ & $43.30 \pm 5.18$ & $0.21 \pm 0.03$ & $28.71 \pm 3.72$ \\
\hline \multirow{4}{*}{ S2 } & \multirow{4}{*}{ Cape Flotsky } & 2014 & $3.51 \pm 0.64$ & $17.81 \pm 1.43$ & $0.05 \pm 0.01$ & $20.03 \pm 1.51$ \\
\hline & & 2017 & $2.52 \pm 0.46$ & $13.11 \pm 1.84$ & $0.04 \pm 0.01$ & $24.0 \pm 2.21$ \\
\hline & & 2018 & $1.32 \pm 0.15$ & $20.93 \pm 2.51$ & $0.10 \pm 0.01$ & $20.92 \pm 1.88$ \\
\hline & & 2019 & $4.75 \pm 0.52$ & $15.20 \pm 1.82$ & $0.04 \pm 0.01$ & $21.32 \pm 2.61$ \\
\hline \multirow{5}{*}{ S3 } & \multirow{5}{*}{ Repino } & 2014 & $3.91 \pm 0.44$ & $27.38 \pm 5.16$ & $0.09 \pm 0.03$ & $15.42 \pm 0.91$ \\
\hline & & 2016 & $2.89 \pm 0.43$ & $19.22 \pm 3.84$ & $0.04 \pm 0.01$ & $9.54 \pm 0.85$ \\
\hline & & 2017 & $3.01 \pm 0.51$ & $24.86 \pm 2.98$ & $0.06 \pm 0.02$ & $16.89 \pm 3.38$ \\
\hline & & 2018 & $2.51 \pm 0.38$ & $17.52 \pm 2.34$ & $0.09 \pm 0.03$ & $17.82 \pm 2.53$ \\
\hline & & 2019 & $3.29 \pm 0.46$ & $18.72 \pm 1.87$ & $0.11 \pm 0.02$ & $17.81 \pm 1.91$ \\
\hline \multirow{5}{*}{ S4 } & \multirow{5}{*}{ Dubki } & 2014 & $3.59 \pm 1.25$ & $26.32 \pm 4.14$ & $0.06 \pm 0.02$ & $15.60 \pm 1.84$ \\
\hline & & 2016 & $3.42 \pm 0.68$ & $16.09 \pm 3.22$ & $0.10 \pm 0.03$ & $19.81 \pm 4.75$ \\
\hline & & 2017 & $3.54 \pm 1.28$ & $26.22 \pm 4.98$ & $0.51 \pm 0.15$ & $19.01 \pm 4.75$ \\
\hline & & 2018 & $2.98 \pm 0.27$ & $19.93 \pm 3.39$ & $0.08 \pm 0.02$ & $36.72 \pm 6.98$ \\
\hline & & 2019 & $4.41 \pm 0.53$ & $26.51 \pm 2.92$ & $0.14 \pm 0.02$ & $18.73 \pm 2.22$ \\
\hline \multirow{5}{*}{ S5 } & \multirow{5}{*}{ Lomonosov } & 2014 & $6.87 \pm 1.82$ & $45.67 \pm 3.89$ & $0.15 \pm 0.11$ & $16.78 \pm 2.10$ \\
\hline & & 2016 & $11.51 \pm 2.02$ & $44.21 \pm 4.51$ & $0.19 \pm 0.09$ & $22.71 \pm 4.48$ \\
\hline & & 2017 & $6.23 \pm 1.56$ & $77.61 \pm 7.01$ & $0.53 \pm 0.16$ & $34.01 \pm 5.11$ \\
\hline & & 2018 & $5.91 \pm 1.18$ & $59.02 \pm 6.49$ & $0.29 \pm 0.03$ & $24.22 \pm 2.11$ \\
\hline & & 2019 & $7.10 \pm 0.64$ & $53.11 \pm 6.37$ & $0.31 \pm 0.05$ & $20.62 \pm 2.53$ \\
\hline \multirow{4}{*}{ S6 } & \multirow{4}{*}{ Big Izhora } & 2014 & $2.54 \pm 0.49$ & $13.04 \pm 2.45$ & $0.05 \pm 0.02$ & $12.69 \pm 3.08$ \\
\hline & & 2017 & $2.14 \pm 0.43$ & $12.41 \pm 2.61$ & $0.05 \pm 0.01$ & $12.53 \pm 2.51$ \\
\hline & & 2018 & $1.01 \pm 0.11$ & $9.68 \pm 1.16$ & $0.03 \pm 0.01$ & $14.01 \pm 2.24$ \\
\hline & & 2019 & $3.11 \pm 0.03$ & $21.12 \pm 1.69$ & $0.06 \pm 0.01$ & $18.90 \pm 1.73$ \\
\hline
\end{tabular}




\begin{tabular}{|c|c|c|c|c|c|c|}
\hline \multirow{5}{*}{ S7 } & \multirow{5}{*}{$\begin{array}{c}\text { Grafskaya } \\
\text { Bay }\end{array}$} & 2014 & $3.32 \pm 0.92$ & $38.69 \pm 5.31$ & $0.29 \pm 0.05$ & $12.97 \pm 2.39$ \\
\hline & & 2016 & $8.93 \pm 2.23$ & $40.81 \pm 4.49$ & $0.13 \pm 0.03$ & $18.92 \pm 4.73$ \\
\hline & & 2017 & $5.35 \pm 1.34$ & $32.32 \pm 5.87$ & $0.08 \pm 0.03$ & $17.71 \pm 3.54$ \\
\hline & & 2018 & $1.25 \pm 0.21$ & $11.71 \pm 1.87$ & $0.05 \pm 0.01$ & $13.21 \pm 2.11$ \\
\hline & & 2019 & $6.74 \pm 0.81$ & $29.20 \pm 2.63$ & $0.17 \pm 0.02$ & $20.52 \pm 2.70$ \\
\hline \multirow{5}{*}{ S8 } & \multirow{5}{*}{$\begin{array}{c}\text { Koporskaya } \\
\text { Bay }\end{array}$} & 2014 & $7.13 \pm 0.44$ & $11.22 \pm 2.28$ & $0.09 \pm 0.01$ & $6.22 \pm 1.78$ \\
\hline & & 2016 & $13.10 \pm 1.44$ & $16.30 \pm 3.59$ & $0.11 \pm 0.03$ & $9.54 \pm 2.86$ \\
\hline & & 2017 & $3.01 \pm 0.51$ & $11.10 \pm 2.78$ & $0.10 \pm 0.04$ & $8.05 \pm 0.97$ \\
\hline & & 2018 & $2.47 \pm 0.29$ & $10.61 \pm 1.59$ & $0.06 \pm 0.02$ & $8.29 \pm 0.99$ \\
\hline & & 2019 & $5.75 \pm 0.46$ & $11.65 \pm 1.28$ & $0.07 \pm 0.01$ & $8.01 \pm 0.72$ \\
\hline \multirow{5}{*}{ S9 } & \multirow{5}{*}{ Luga Bay } & 2014 & $1.90 \pm 0.87$ & $7.13 \pm 0.86$ & $0.08 \pm 0.03$ & $14.78 \pm 1.12$ \\
\hline & & 2016 & $1.35 \pm 0.41$ & $9.24 \pm 1.48$ & $0.05 \pm 0.01$ & $16.21 \pm 1.45$ \\
\hline & & 2017 & $1.63 \pm 0.58$ & $7.81 \pm 1.56$ & $0.03 \pm 0.01$ & $15.32 \pm 1.64$ \\
\hline & & 2018 & $1.06 \pm 1.01$ & $9.57 \pm 1.44$ & $0.03 \pm 0.01$ & $9.62 \pm 1.01$ \\
\hline & & 2019 & $2.16 \pm 0.22$ & $7.09 \pm 0.85$ & $0.03 \pm 0.01$ & $16.61 \pm 2.01$ \\
\hline
\end{tabular}

The distribution of metals in surface sediments varied significantly both from spot to spot along the coast and from year to year. At the Primorsk station (S1) over the study period there was a decrease in copper content in the bottom sediments (55 to $11 \mathrm{ppm}$ ). At the remaining stations on the northern coast (S2-S4) the copper content changed from 1.5 to $4.7 \mathrm{ppm}$. As far as the southern coast of the eastern part of the Gulf of Finland was concerned, the maximum copper concentration of $7.0 \mathrm{ppm}$ on average was found at the Lomonosov station. From 2014 to 2019 in places with algae growing at the highest rate (S7, S8), the average copper concentrations amounted to 5.1-6.2 ppm, with the concentrations increased to 9.0$11.0 \mathrm{ppm}$ in 2016.

On the northern coast of the eastern part of the Gulf of Finland the bottom sediments at the Primorsk station contained the highest concentration of zinc that ranged from 44 to 77 $\mathrm{ppm}$. The highest levels of zinc contamination on the southern coast were found in the bottom sediments around the Lomonosov station and in Koporskaya Bay (the average values were 56 and $30 \mathrm{ppm}$, respectively).

In the northern and southern coastal zones of the eastern part of the Gulf of Finland the cadmium concentrations ranged from 0.03 to $0.21 \mathrm{ppm}$. In 2017 the cadmium content at the Dubki and the Lomonosov stations reached $0.53 \mathrm{ppm}$.

During the study period the highest levels of the lead contamination were observed at the Primorsk and the Lomonosov stations (26-33 ppm and 17-34 ppm, respectively). In 2018, there was an increase in lead content in the bottom sediments at the Dubki station that reached $36 \mathrm{ppm}$.

\section{Conclusion}

In view of the foregoing, it is considered that the year-to-year fluctuations in the heavy metals components are caused by the multi-layered structure of the bottom sediments and the presence of ferriferous fractions that can accumulate microelements which may lead to changes in the bottom sediments sorption abilities.

Increased concentrations of heavy metals are observed in Primorsk and Lomonosov which likely associate with technogenic impacts on the coastal areas because there the seaports are under active construction and operation now.

Besides, ferriferous fractions that can accumulate microelements may influence on the accumulation capabilities of bottom sediments. It has been found that in the Koporskaya and Grafskaya Bays a massive growth of macroalgae lead to further accumulation of metals in 
the coastal zone bottom sediments. The reasons are hypoxia and the release of heavy metals from the decaying algae biomass.

The study had been supported by the state research topic of Scientific Research Center for Ecological Safety of the Russian Academy of Sciences, project No. AAAA-A19-119020190122-6.

\section{References}

1. V. A. Shakhverdov, M. V. Shakhverdova, Izvestia: Hurzen Univ. J. of Humanities \& Sciences, 176, 101-113 (2015).

2. R. L. Levit, V. A. Kudryavtseva, Regional ecology, 3(49), 38-44 (2017).

3. P. N. Linnik, V. A. Zhezherya, N. P. Zhezherya, Ecological chemistry,25(4), 222-240 (2016).

4. Y. I. Gubelit. Mar. Pollut. Bull., 91, 166-172 (2015)

5. Y. I. Gubelit, Y. M. Polyak, T. D. Shigaeva, L. G. Bakina, V. A. Kudryavtseva, Contemp. Probl. Ecol., Vol. 13, No. 2, pp. 113-126 (2020).

6. Y. M. Polyak, T. D. Shigaeva, V. A. Kudryavtseva, V. G. Konakov, Water: Chemistry and Ecology, 1, 11-18 (2017) 